\title{
Spectral Width
}

National Cancer Institute

\section{Source}

National Cancer Institute. Spectral Width. NCI Thesaurus. Code C156496.

The width of the wavelength interval at half maximum amplitude. 